\title{
Cost and Benefit Analysis of Students Online Registration System in Manado State Politechnic
}

\author{
Herry S. Langi \\ Information Technology Dept \\ Manado State Polytechnic \\ North Sulawesi - Indonesia
}

\author{
Yoice R. Putung \\ Electrical Engineering Dept \\ Manado State Polytechnic \\ North Sulawesi - Indonesia
}

\author{
Sonny R. Kasenda \\ Electrical Engineering Dept \\ Manado State Polytechnic \\ North Sulawesi - Indonesia
}

\begin{abstract}
The aims of this study is to identify the feasibility of developing an online re-registration application software. The feasibility of the developed software is calculated by comparing both the benefits and costs of the project using the Payback Period Method. The results show that this software is feasible to develop because the payback time is more than the break event point and smaller than the investment age.
\end{abstract}

\section{General Terms}

Administration, Software, Education.

\section{Keywords}

Analysis, software, registration.

\section{INTRODUCTION}

Expansion of information technology is currently growing rapidly. The needs of information and data processing in many aspects of human life is very important. Technology development affect all area of life very quickly, especially the provision of information for agency or company that requires a precise, fast and accurate data processing system. To support the performance, productivity and efficiency of agency or company is solving management problems [1].Development of an information system is an investment that has a long-term value as well as other project investments. Investment is an activity related to the withdrawal of resources (funds) used to hold capital goods at the present time and with capital goods will produce new product flow in the future. Information system development resources can support each other. As the result, the information system will provide benefits that can be new savings and benefits. If the expected benefits are less than the expended resources, this information system will have no value or improper. Therefore, before the information system is developed, it is necessary to calculate its economic feasibility. This assessment technique is called cost / benefit analysis. The advantages of information systems development are not always measured by the value of money as in other service businesses, but it can be measured by increased working time, service quality or data access speed. Student Registration in each semester is one part of the business process that is in administration of Manado State Polytechnic (Polimdo) where the student apply it in the next semester. The system can play a role in registration without having to come to campus, simple, and can have a positive impact on improving service quality. Student registration system has been widely used by some Universities in Indonesia, but Polimdo has not developed a system that can serve the registration of students either new students or for student registration in each semester. Therefore it is necessary to analyze the costs and benefits for the development of student registration system.

\section{METHODOLOGY}

System analysis can be defined as the decomposition of a complete information system into its component parts including to identify and evaluate the problems that occur so that proposed improvements can be made [2].

The information system is defined by Robert A. Leitch and K. Roscoe Davis in Jogiyanto's book [3], "System Information is a system within an Organization that meet needs processing daily transactions, supporting operations, Managerial and strategic activities of an Organization and provide certain outside parties with the necessary reports.

As a first step to develop student registration system, it is necessary to analyze cost and benefit using Payback Period Method. Payback period in capital budgeting refers to the period of time required to recoup the funds expended in an investment, or to reach the break-even point [4]. This method is a quantitative test used to calculate the length of time required to pay back investment costs in the manufacture of applications that have been issued [5]. Assessment of eligibility for repayment.

- Worthy if the payback time is less than the investment age.

- It is not feasible if the payback period is greater than the investment age.

The formula of the annual payback period cash flows is different

Payback period $=\mathrm{n}+\mathrm{a}-\mathrm{b} / \mathrm{c}-\mathrm{b}+1$ year,

and the formula of the payback period if the annual cash flows are equal :

Payback period $=$ initial investment/Cash Flow +1 year

Period of faster return: Eligible

- Longer refund period: Not Eligible

- If the proposed investment project is more than one then the faster return period is selected

\section{RESULT AND DISCUSSION}

Based on the observations made at the Manado State Polytechnic, that to register every semester, the students must go to campus by showing proof of payment of education's fees to the bank. There are some weaknesses encountered include:

1. There is no registration form available for students

2. Payment receipts are not well documented.

3. Registration is still done through the recording of books by administrative staff. 
4. There can be differences in academic data of students who make re-registration.

\subsection{Payback Period}

From some of the above issues, then performed a cost and benefit analysis to develop an online student re-registration system in Polimdo.

As the requirements, the cost components include

1. Purchase Domain Name \& Server Hosting Rp. 2.100.000

2. Cost Analysis and Research Needs 2x meeting Rp. 200,000

3. Design layout \& Display Rp. 1,200,000

4. Preparation and Implementation of CMS / BackOffice Rp. 1.600 .000

5. Content Creation and Upload Rp. 200,000

6. Maintenance Rp. 1.800 .000

Total Rp. 7,100,000

Calculation payback period (PP)

Age of investment: 5 years

Investment Value: Rp 7,100,000

Process Year 1: Rp 4.100.000

$\mathrm{PP}=\mathrm{Rp} 7.100 .000 / \mathrm{Rp} 4.100 .000$

$\mathrm{PP}=1.73$ Years (approximately 1 year 8 months),

1.73 Years $<(5$ years investment age $)=$ Eligible

From the above calculation is known that the return period can be achieved in the year- 0 or the first year if the application is made directly used for academic needs, in detail is 1.73 . It can be concluded that the implanted system design will break even in approximately 1 year 8 months to 9 months, which means that after 1 year 8 months will begin to take advantage of the system. Which means the system is worth developing because the payback time more to break even or small from the age of investment.

\subsection{Return on Investment Method.}

The method of return on investment is used to measure the percentage of benefits generated system compared with the cost incurred [5]. Return on Investement (ROI) of system development is calculated as follows:

Feasibility assessment for ROI:

- Worth if ROI>0

- Not feasible if ROI $<0$

Costs

Cost Year $0=\operatorname{Rp} 7,100,000$

Fee Year 1 = Rp 4.100.000

Fee Yea $2=\operatorname{Rp} 4.100 .000$

Fee Year $3=$ Rp 4.100 .000

Total $=\operatorname{Rp~19,400,000}$

From some questions we ask students is whether it is necessary to re-register online and whether the presence of online registration system will be able to provide benefits, then the results show from 25 students as respondents strongly agree because the registration on every semester can be done anywhere without having to come to campus, so save cost and time.

The illustration of the cost and benefits of the Registration System is as in table 1 below

\begin{tabular}{|c|l|l|}
\hline Benefits & \multicolumn{1}{|c|}{ Results } & \multicolumn{1}{|c|}{ Cost } \\
\hline Tangible & $\begin{array}{l}\text { Reduced transportation } \\
\text { costs of students and } \\
\text { committees, savings of } \\
\text { stationery }\end{array}$ & $\begin{array}{l}\text { System } \\
\text { development } \\
\text { services }\end{array}$ \\
\hline Intangible & working time & $\begin{array}{l}\text { The loss of time } \\
\text { Free }\end{array}$ \\
\hline
\end{tabular}

\section{CONCLUSION}

Based on the results of the analysis, it can be concluded:

1. The results of the feasibility study of the student registration software re-eligible to be developed.

2. Cost and benefit analysis can help Polimdo make the right decisions in developing an online student registrasion system.

3. Recommendation for State Polytechnic of Manado in the future is process of verification system of online registration of web based students can be developed and used in registration process.

\section{REFERENCES}

[1] Tina Martiana , Irfan Analisis Perancangan Sistem Informasi Pendaftaran Mahasiswa Baru STMIK Jakarta STI\&K Berbasis WEB, Jurnal Ilmiah KOMPUTASI, Volume 15 Nomor : 2, Desember 2016 ISSN : 1412 9434

[2] Mustakini, Jogiyanto Hartono. Sistem Informasi Teknologi. Yogyakarta : Andi Off-set.

[3] Chr.Jimmi.L.gaol "Sistem Informasi Managemen". Grasindo 2008.

[4] Farris, Paul W.; Neil T. Bendle; Phillip E. Pfeifer; David J. Reibstein (2010). Marketing Metrics: The Definitive Guide to Measuring Marketing Performance. Upper Saddle River, New Jersey: Pearson Education, Inc. ISBN 0-13-705829-2. The Marketing Accountability Standards Board (MASB) endorses the definitions, purposes, and constructs of classes of measures that appear in Marketing Metrics as part of its ongoing Common Language: Marketing Activities and Metrics Projec.

[5] Saputra, Febri and Hannah, Merrieayu Puspita (2013) Sistem Informasi Akademik Berbasis Web Pada Global English Language Center. STMIK MDP http://eprints.mdp.ac.id/834/ 